\title{
Online Information System for Archiving Documents And Letters Requests at The Sub-District Level
}

\author{
Nanang Hunaifi ${ }^{1}$, Agung Baitul Hikmah ${ }^{2}$, Maxsi Ary ${ }^{3}$ \\ \{masnaing@gmail.com¹, agung.abl@bsi.ac.id ${ }^{2}$, maxsiary@gmail.com ${ }^{3}$ \} \\ AMIK BSI Bandung ${ }^{1,3}$, AMIK BSI Tasikmalaya ${ }^{2}$
}

\begin{abstract}
Population administration is a way for a country to keep a continuous and complete record of birth and death, including personal data and employment/business. This is very important to do both at the national and state levels as a policy and planning. Even the WHO considers it the most reliable statistical source. In Indonesia, there are still many residents who do not have a KTP. Management of population registration is the responsibility of the government so that each resident is registered administratively and in accordance with the Law. The absence of a system needed for the administration of population is one of the obstacles in population administration registration. This study aims to develop an online information system for archiving document and letter request at the sub-district level. The system was designed with the waterfall method and Unified Modeling Language (UML) modeling was then implemented using the PHP MySQL web programming language. The results of this study are the development of an online information system for archiving documents and letter requests called "Sipadu" at the Lembang Sub- District West Bandung District with $84.50 \%$ of respondents agreed that this system provides convenience.
\end{abstract}

Keywords: Egoverment, Information System, Internet, Letter, Website

\section{Introduction}

Population and civil registration administration is a way for a country to keep a continuous and complete record of birth and death, including personal data and employment/business. This is very important to do both at the national and state levels as a policy and planning. Even the World Health Organization (WHO) considers it the most reliable statistical source. The absence of a system needed for the administration of population, birth and death data is one of the obstacles in population administration and civil registration [1]. In Indonesia, there are still many residents who do not have a National Identity Card (KTP). Permanent residents, migrants or relocated residents often do not report to local authorities. The events of birth, death, marriage, issuance of new family cards are still often ignored. Even residents who frequently change addresses and have multiple identities, especially among students [2]. In fact, in Indonesian Law Number 24 Year 2013 Article 3 and 4 concerning Population Administration it has been explained that each resident is required to report population events and important events they experienced to the implementing agency by fulfilling the required requirements in population registration and civil registration. Population registration is the process of recording population data on population reports and population data as well as the issuance of population documents in the form of identity cards 
or Population Certificates. Management of population registration is the responsibility of the government so that each resident is registered administratively and in accordance with the Law [3].

However, in its implementation, to make or get a certificate, it is not certain that people can be directly served. Depending on whether the relevant apparatus is in place or not [4]. The existence of extortion issues and processes that seem complicated make people judge that the management of population data is a complicated thing that makes people lazy and often ignore it. This of course is a loss for all parties, both the state through implementing agencies and the people itself. One of the negative impacts of not recording population data is that there is a dual identity of the population that can be misused, unknown newcomers are often used for terrorism activities, obstruction of other arrangements that require a population certificate such as making SIM, BPJS, NPWP and so on. This study aims to develop an online information system for archiving document and letter request at the Lembang Sub-District West Bandung District. This system is expected to simplify and accelerate the process of making letters and processing of population administration in implementing agencies. With the convenience offered, of course, indirectly and slowly will make people who used to feel complicated becomes easier. This system will also support the Open Government program, for example, with openness (transparency) and the certainty of costs and time of service so as to prevent the extortion. The Research Flow can be seen in Figure 1. Letters handled by the system temporary are limited to only 5 (five) types of letters, below:

1. Job Seekers Card

2. Domicile of business

3. Certificate of Business

4. Death Certificate

5. Certificate of Heirs

6. Certificate of Domicile of Residence 


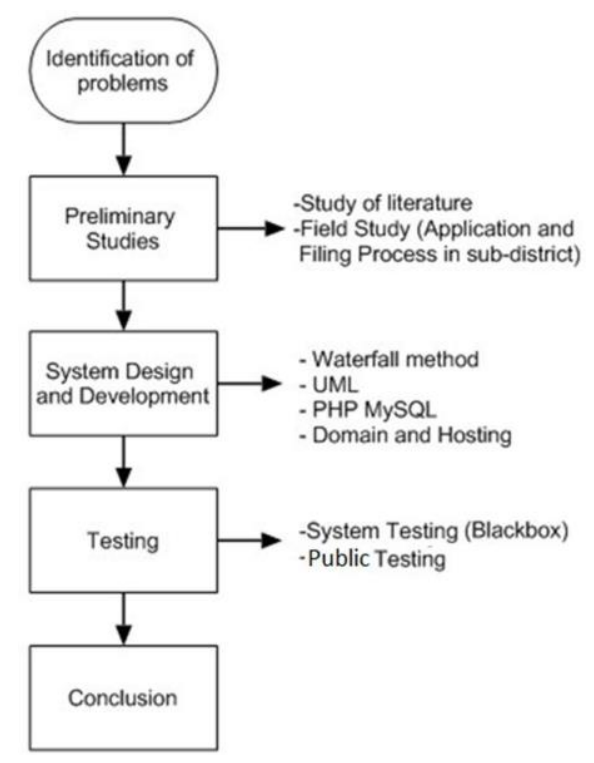

Fig. 1. Research Flow.

\subsection{Information Systems}

The system means that in a group of people who work together regularly with the same goals and functions, to reach a decision or achieve the expected goals. While information is the result of data that has been processed to be more useful and meaningful for users to reduce doubts in the decision making process in a situation. So, information systems can be defined as software that can help manage and analyze data. The purpose of the information system itself is to transform raw data into useful information that can be used for decision making in an organization. In addition, information systems are a set of integrated components to collect, record and process data to provide information, knowledge, and digital products. Here are some information system components [5]:

1. Input component.

2. Model Components.

3. Output Component.

4. The Technology Component.

5. Database Component.

6. Control Component.

\subsection{Web Server}

Web server functions to send website files that will be accessed by clients through predetermined communication protocols. When the client accesses the website using a web browser, at that time the client will send a service request in the form of a file or website page contained on a web server. Furthermore, the server that acts as the service manager will 
respond by sending the requested web page file or refusing if the intended web page is not available. Currently there are many web server software available on the internet. In having a web server software, it is usually adjusted to the provider and hosting service package that will be used. One example of web server software that is widely used is Apache. Apache web server software is capable of running on various OSes such as Unix, BSD, Linux, Microsoft Windows and Novell Netware and other OS platforms. As for some support from Apache are as follows [6]:

1 Access Control, which is a control that is able to run refers to the host name and IP number of the Common Gateway Interface (CGI) and the most widely used is the Practical Extraction and Report Language (perl) supported by Apache by placing it as a module (mod_perl).

2 Personal Home Page / PHP Hypertext Processor (PHP), a program with methods such as CGI that processes text and works on the server. Apache supports PHP by placing it as one of its modules (mod_php). This will make PHP work better.

\subsection{Architectural Diagram}

Unified Modeling Language (UML) Diagram Architecture is a method for visually modeling object-oriented system designs. Another definition of UML is a language that has become a standard in visualization, design and for system software documentation. Currently UML has become a standard in writing for blueprint software. There are several objectives and functions of UML utilization including [7]:

1. Able to convey visual modeling language to its users with various programming and software engineering processes.

2. Able to integrate existing good implementation in modeling.

3. Able to convey models that are ready to use and included in expressive visual modeling languages to develop systems and exchange models easily.

4. Able to be used as a blueprint, because it is very complete and detailed in its next design will facilitate the implementation of coding a program.

5. Being able to model the system with an object oriented concept, so that it can not only be used to model software.

6. Being able to create a modeling language that can be utilized by humans and machines in the future.

\section{Method}

\subsection{Waterfall Method}

Waterfall method is a process of developing information systems and websites in a structured and sequential manner starting from determining the problem, analyzing needs, implementing, integrating, system testing, website placement and maintenance. Making a website using the waterfall method is very suitable to do especially on large scale websites, because it will involve management and complex systems. This method requires a systematic and sequential approach in software development which is usually called the classic life cycle, starting from the level of system progress through analysis, design, coding, testing and maintenance. System 
Information Engineering and Modeling is part of a larger system, the work starts from making elements of the requirements of all system elements and preparing a subset into software development. This is important to do when the software communicates with hardware, people and databases. Systems engineering and modeling focus on gathering needs at the system level with little design and analysis. The stages in developing the waterfall model include [8]:

1. Analysis and definition of requirements carried out by way of service, limitations, and system goals that have been determined in consultation with the user.

2. System and software design, namely activities to determine the overall system architecture.

3. Implementation and testing, namely the implementation of the design of a software which is realized as a series of programs.

4. System integration and testing, which is a unit program process that is integrated or tested as a complete system to ensure that the system requirements are met.

5. Operation and maintenance

\subsection{Architecture diagram and PHP MySQL}

Unified Modeling Language (UML) is a collection of tools that are used as an abstraction of an object-based system or software. UML is also a way to facilitate the development of sustainable applications. Applications or systems that are not documented generally will hamper development because the developer must search and learn the program code. UML can be used as a tool for knowledge transfer about the system to be developed from one developer to another developer. Not only that knowledge transfer can be done to people or businesses and anyone who can understand a system using UML. PHP is a web programming language in the form of scripts that are most widely used today. PHP is widely used to develop web-based information systems and dynamic websites and does not rule out the possibility of being used for other uses. MySQL is a database management system software SQL (database management system) or also called a multithreaded and multi-user DBMS. MySQL is available in free licensed software under the GNU General Public License (GPL), but there is also a paid version under a commercial license for certain uses where the use is different from the use of the GPL [6].

\subsection{Usability Testing}

Usability testing is a method that use to test a product that is usually carried out by producers with potential customers. This trial was conducted for people around, for example to employees themselves and their families. If it turns out that the results obtained are easy to use and do not seem complicated, then the product is likely to be accepted by the market (by consumers). Usability testing is generally carried out on digital products such as web applications, although it can also be used for non-digital products such as books. One way to test usability is to use the USE Questionnaire, which is a user satisfaction assessment technique used in computer science that is created by giving general questions to all prospective users. The USE Questionnaire provides a quantitative method of collecting data, evidence, or information expressed in numerical terms. In this study, samples of the community and implementing agency apparatus were taken as examiners of the system's effectiveness with a total of 30-40 people [9]. 


\section{Results}

\subsection{Use Case Diagram}

Sipadu Use Case Diagram can be seen in Figure 2.

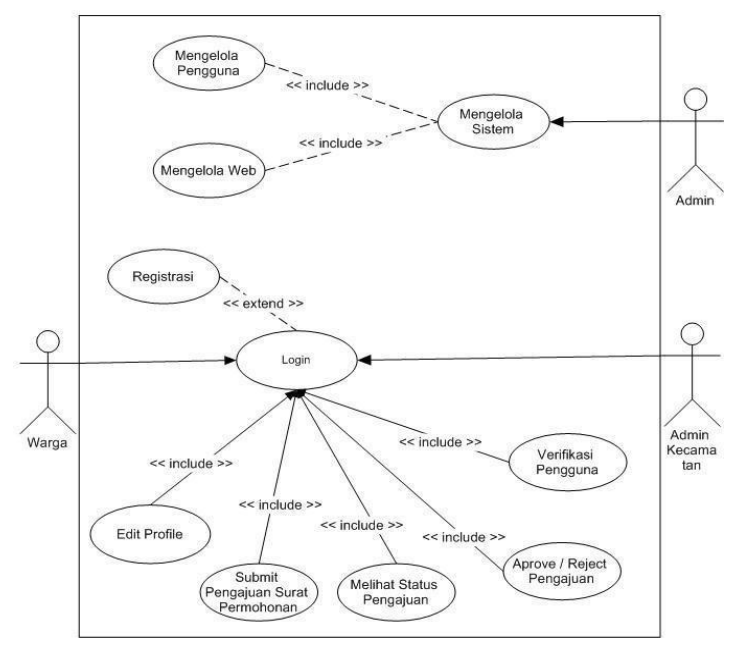

Fig. 2. Sipadu's Use Case.

There are 3 actors in this system, including the admin, district admin and residents. Admin get access rights to manage this system in full from managing the web, system, news, manage users and others. Citizens' actors have access rights to register, edit profiles, fill out submission forms / make submission reports and check the status of letter requests that have been submitted through this system. Sub-district admins play the role of accepting submissions from residents and can take action to accept (Approve) submissions or reject (Reject) submissions.

\subsection{System Implementation}

Every user must have an account in order to use the SIPADU system. The registration for a new account can be done by filling in the personal data on the registration page and can only be used after verification by the admin. The registration page are shown in Figure 3. 


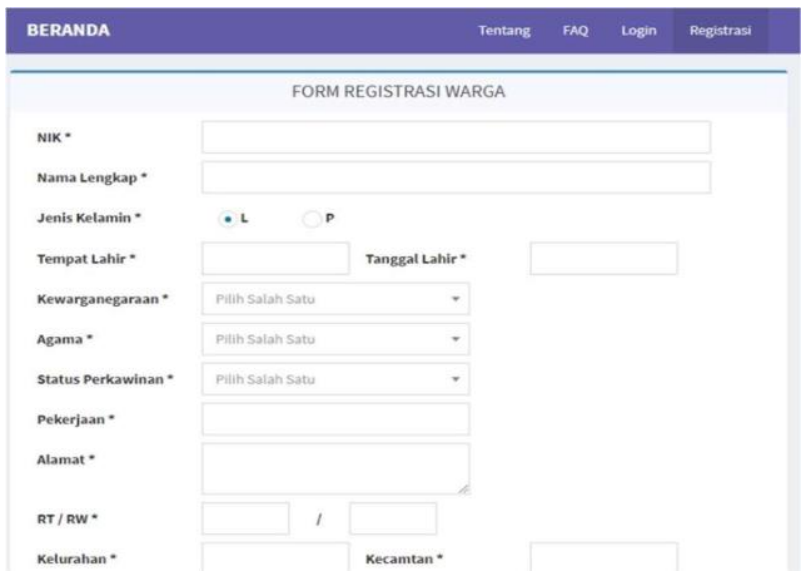

Fig. 3. Citizens Registration Form Page.

If the residents do not have an account, they are required to register first by selecting the registration form then filling in their personal identities according to their National Identity Card (KTP). On this registration form, residents can understand the procedure for creating an account in an information system before later making a file submission. This can be seen in Figure 4.

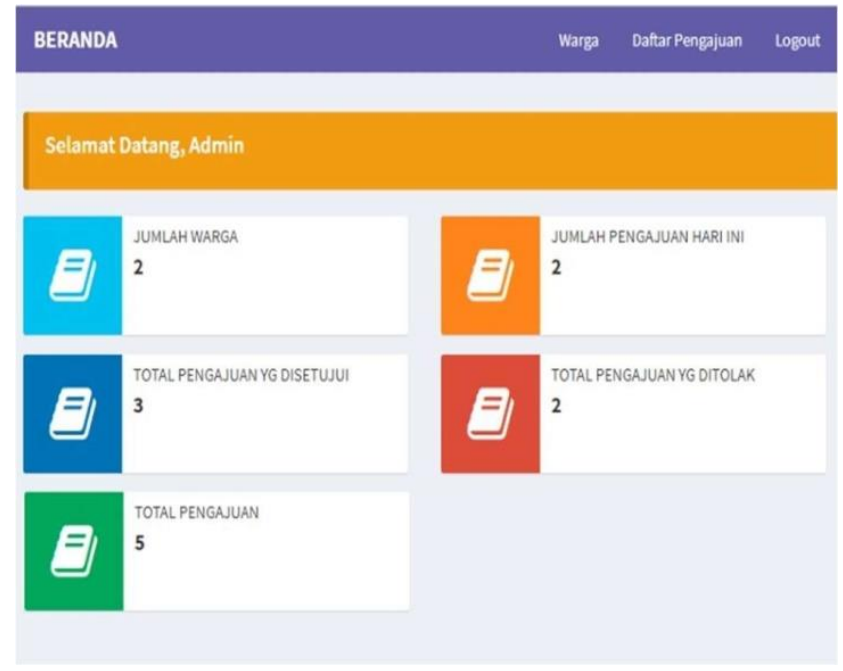

Fig. 4. Admin Home Page.

On the district admin page will display a list of submissions made by citizens, here the district admin can see data on the number of citizens who have registered, the number of submissions today, the total submissions, the total submissions approved and the total submissions rejected. This can be seen in Figure 5. 


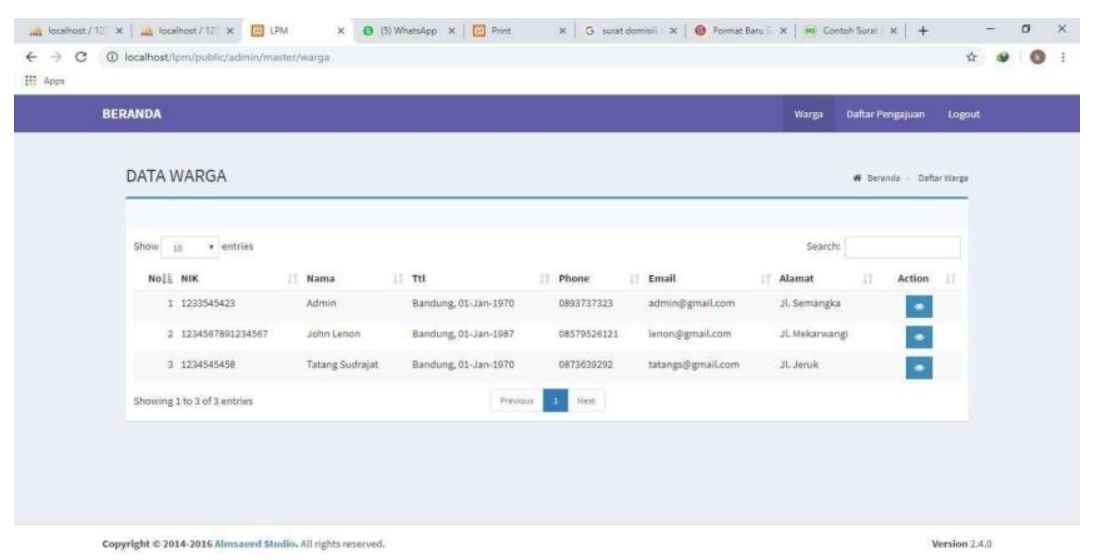

Fig. 5. Citizen Data.

After the residents have successfully registered, the sub district admin can see the citizens' data on the Citizens Data page. On the Citizens Data page, the subdistrict admin can see and check data such as the NIK number, Name, Place of birth date, Tel No, Email and Citizen Address. Then the District Admin can take actions to edit or delete the citizens data. This can be seen in Figure 6.

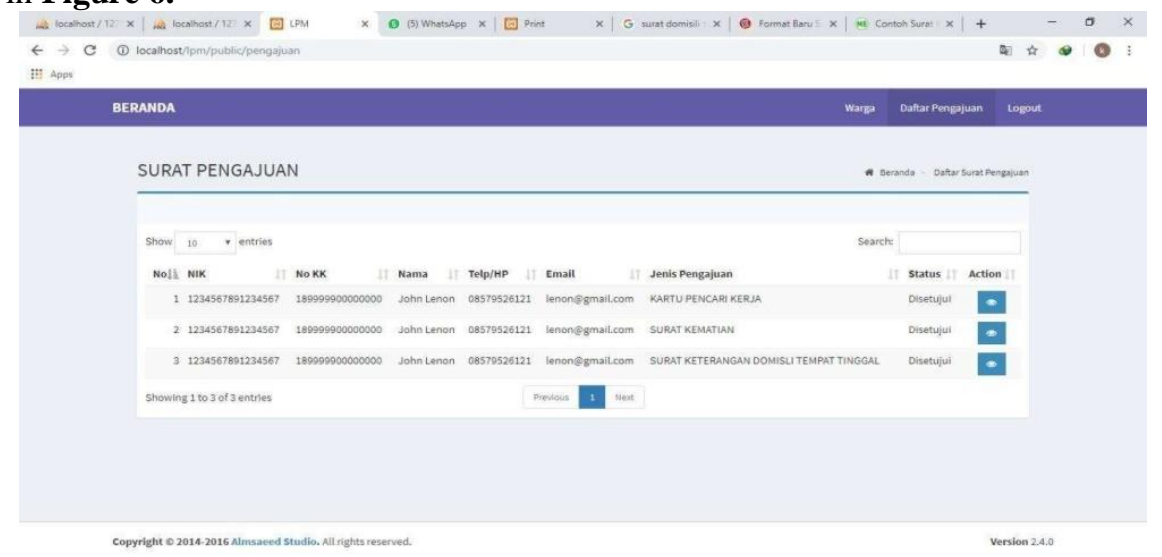

Fig. 6. Letter Submission.

On the Submission Letter page, there is NIK, Name, Phone, Email, Type of Submission, Status and Action. From the page the submission letter will appear in the District Admin page and in the citizen page account. The subdistrict admin can see the type of submission and take actions such as approving the type of submission or rejecting the proposal while the Citizens can only see the status of whether they are approved or rejected. This can be seen in Figure 7. 


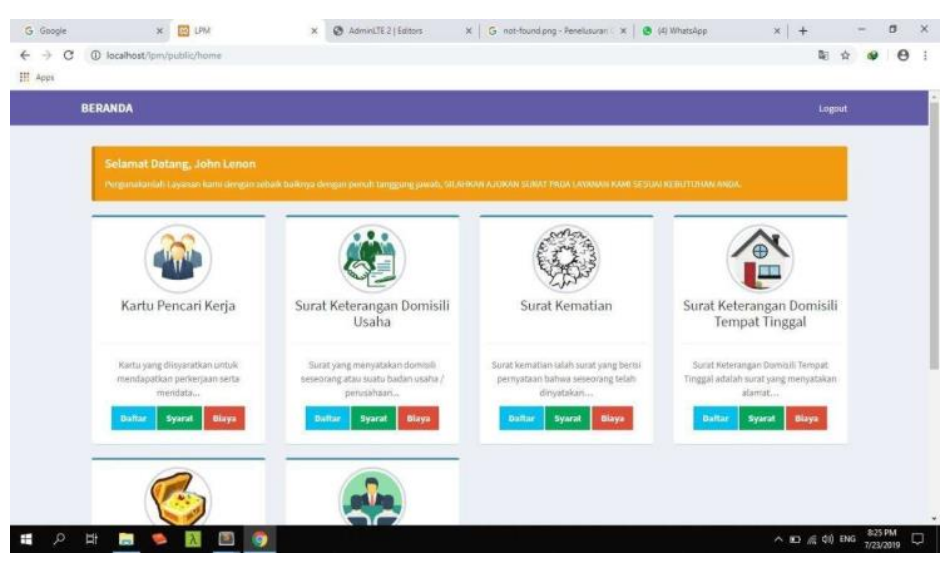

Fig. 7. Citizens Account Home Page.

On the homepage of the residents' account, several menu options appear to be submitted according to the needs of their respective residents, including the menu of job seekers, business domicile certificates, death certificates, domicile certificates of residence and others. Before making a submission, residents can first read the terms and costs in carrying out the plan for filing the file. This can be seen in Figure 8.

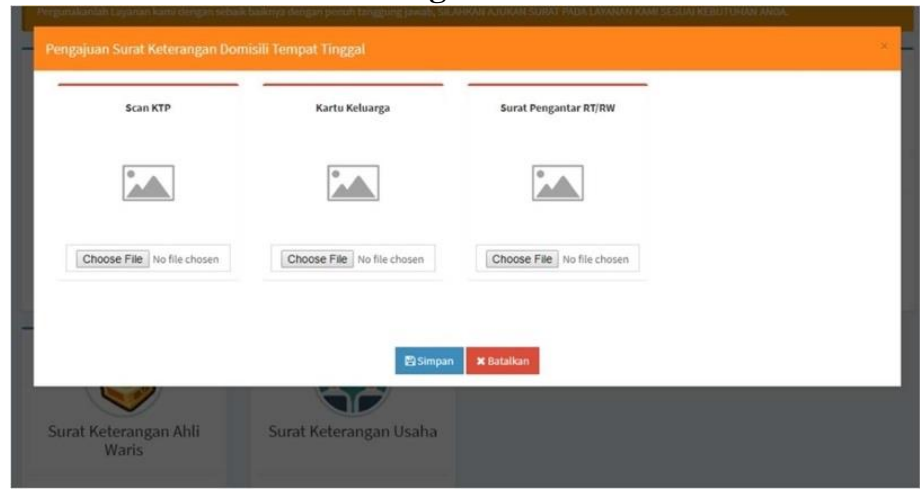

Fig. 8. Kartu Pencari Kerja Upload file page.

In this filing information system, especially in the section of the page for residents, to make a submission every citizen is required to enter the required files. For example, if you are going to submit an application to have a job search card, you must prepare a photo of yourself, ID card, diploma and family card which is then scanned first to be uploaded into this filing information system. The Black Box Testing result can be seen in Table 1.

Table 1. Black Box Testing.

\begin{tabular}{lll}
\hline \multicolumn{1}{c}{ Function } & \multicolumn{2}{c}{ Results } \\
\cline { 2 - 3 } & & Excpected Status \\
\hline Home page & Displays the main page & Success \\
Approve account & Activate account & Success \\
Login / Register & Displays the login or registration page & Success
\end{tabular}




\begin{tabular}{lll}
\hline \multicolumn{1}{c}{ Function } & \multicolumn{2}{c}{ Results } \\
\cline { 2 - 3 } & & Excpected Status \\
\hline Fill out the Submission Form & Displays the submission form page & Success \\
Submitting Submissions & Submission Submitted & Success \\
See Submission Status & Displays Approve / Reject Status & Success \\
\hline
\end{tabular}

\subsection{Public Test Questionnaire}

Sipadu users as respondents have been given a questionnaire using Google Form to test the level of system acceptance. Below is a list of questions given to 40 respondents consisting of residents and sub-district officials.

1. Sipadu's appearance is interesting

2. The appearance of Sipadu is easy to understand

3. Use of Sipadu is easy to use

4. The information displayed on the online filing and request information system is useful

5. This online filing and application information system can help citizens make requests

6. Online filing and application information systems provide fast responses

7. The menus and navigation on Sipadu are easy to understand

8. I feel satisfied after using this online filing and application information system

9. I want to have this online filing and application information system

10. I would recommend this online filing and application information system through friend or family

The table below presents the results of the questionnaire calculation using the percentage calculation with equation in the Equation 1.

$$
\operatorname{PR}(\%)=(\mathrm{NRR} / \mathrm{NR}) \times 100 \%
$$

Information :

PR = Percentage Results

NRR = Number of Respondent Ratings

$\mathrm{NR}=$ Number of Respondents

Based on the results of the questionnaire testing in the public test questionnaire table, it can be seen that 40 respondents gave a positive appreciation of $84.50 \%$. Therefore it can be concluded that the existence of an online document archiving information system and letter can help users to make a submission at the district level online. Questionare Calculation Result can be seen in Table 2, and the Sipadu Testing documentation can be seen in Figure 9.

Table 2. Questionnaire Calculation Results.

\begin{tabular}{|c|c|c|c|c|}
\hline \multirow{3}{*}{$\begin{array}{c}\text { Question } \\
\text { No. }\end{array}$} & \multicolumn{4}{|c|}{ Answer } \\
\hline & \multicolumn{3}{|c|}{ Yes } & No \\
\hline & Total & $\%$ & Total & $\%$ \\
\hline 1 & 39 & 97.50 & 1 & 2.50 \\
\hline
\end{tabular}




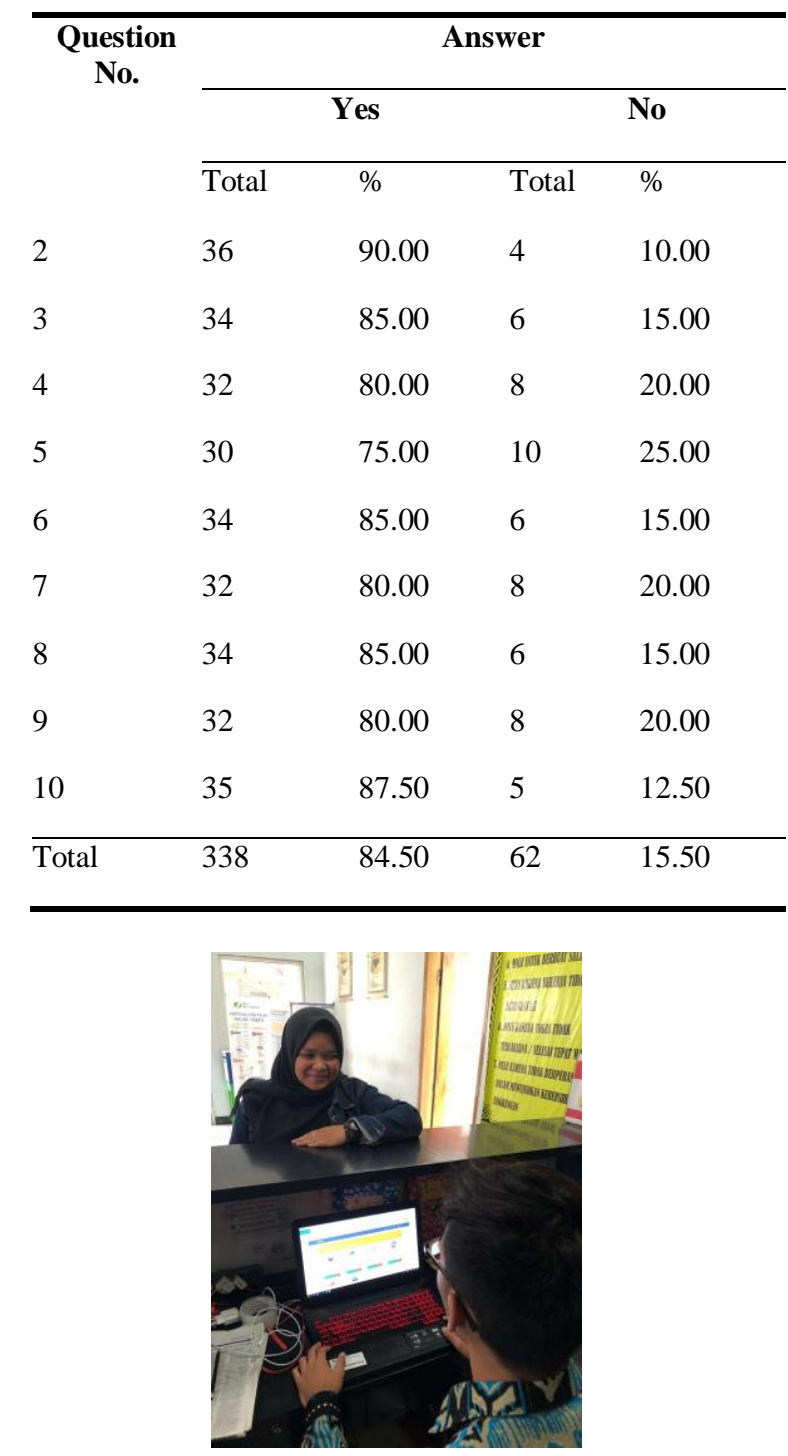

Fig. 9. Sipadu Testing at the Lembang Sub-District West Bandung District Office

\section{Conclusion}

Based on this research, some conclusions are:

1. The absence of a system needed for the administration of population, birth and death data at the Lembang Sub-District West Bandung District is one of the obstacles in population administration and civil registration. 
2. The development of an online information system for archiving documents and letter requests called "Sipadu" at the Lembang Sub-District West Bandung District with $84.50 \%$ of respondents agreed that this system provides convenience.

3. This system is expected to simplify and accelerate the process of making letters and processing of population administration in implementing agencies. With the convenience offered, of course, indirectly and slowly will make people who used to feel complicated becomes easier. This system will also support the Open Government program, for example, with openness (transparency) and the certainty of costs and time of service so as to prevent the extortion.

\subsection{Recomendation}

Some recommendations from the author are:

1. Socialization of system implementation needs to be done by the sub-district so that citizens can use this facility.

2. Public testing with other methods can be done as an evaluation. Long-term testing is needed in order to know the ability of the system to handle requests in large quantities.

3. Other features such as instant messaging can be added to provide ease of interaction between citizens and admin.

Acknowledgement. Thanks to the Directorate General of Strengthening Research and Development of the Ministry of Research, Technology and Higher Education of the Republic of Indonesia for funding so that this research can be carried out.

\section{References}

[1] Mohanty, I., Gebremedhin, T.A.: "Maternal autonomy and birth registration in India: Who gets counted?," Plos One, vol. 13, no. 3, pp. 1-19 (2018)

[2] Ibrahim, A., Rifai, A., Oktarina, L.: "RANCANG BANGUN APLIKASI PENCATATAN DATA KEPENDUDUKAN KELURAHANPAHLAWAN BERBASIS WEB," Informational System Journal (JSI), vol. 8, no. 1, pp. 947-957(2016)

[3] Asmar, A.R.: "PELAYANAN PUBLIK DI BIDANG ADMINISTRASI KEPENDUDUKAN (Studi Kasus Kota Makassar)," Jurisprudentie, vol. 4, no. 1, pp. 1-24, (2017)

[4] Sasono, J., Darwanto, A., Supardi, S.: "ADMINISTRASI DESA ONLINE DESA NOGOSARI KECAMATAN NGADIROJO KABUPATEN PACITAN," Journal of Service LPPM Untag Surabaya, vol. 02, no. 01, pp. 85-90, (2016)

[5] Sutabri, T., Analisis Sistem Informasi. CV. Andi Offset. Yogyakarta, Indonesia. (2012)

[6] Hikmah, A.B., Supriadi, D., Alawiyah, T.: Cara Cepat Membangun Website dari Nol. CV. Andi Offset. Yogyakarta, Indonesia. (2015)

[7] Muslihudin, M., Oktafianto, O.: Analisis dan Perancangan Sistem Informasi Menggunakan Model Terstruktur dan UML. CV. Andi Offset. Yogyakarta, Indonesia (2016)

[8] Hikmah, A.B., Supriadi, D.: "Rancang Bangun Aplikasi Pemesanan Tiket Bus Online Berbasis Web dengan menggunakan metode waterfall," Jutekin (Informatic Engineering Journal), vol. 2, no. 2, pp. 49-60. (2014)

[9] Firmansyah, R.: "USABILITY TESTING DENGAN USE QUESTIONNAIRE PADA APLIKASI SIPOLIN PROVINSI JAWA BARAT," Swabumi (Suara Wawasan Sukabumi), vol. 6, no. 1, pp. 1-7. (2018) 